Bangladesh J. Plant Taxon. 26(2): 259-268, 2019 (December)

(C) 2019 Bangladesh Association of Plant Taxonomists

\title{
MORPHOLOGICAL, PALYNOLOGICAL AND PHYLOGENETIC RELATIONSHIPS OF GLAUCIUM MILL. IN TURKEY
}

\author{
Fatma Mungan Kiliç ${ }^{*}$, Kemal Yildiz ${ }^{1}$, Muhammet Burak Batir ${ }^{1}$, \\ MuRAT KILIÇ ${ }^{1}$ AND İLKeR BÜYÜK ${ }^{2}$ \\ Department of Crops and Animal Production, Kizlltepe Vocational Training \\ High School, Artuklu University, Kızlltepe, Mardin, Turkey
}

Key words: Glaucium; matK; ITS3-6 DNA; Phylogeny; Subsection; Turkey.

\begin{abstract}
Glaucium taxa were investigated in terms of their morphological, palynological and phylogenetical characteristic. The results of this study show differences between the taxa in some of these characteristics, especially in micromorphology and formation of clades in phylogenetic trees based on the matK and ITS3-6 DNA sequence data. Based on the findings of the molecular analyses supported by morphological data (stem's trichomes), the genus Glaucium of Turkey was divided into subsections Glabrousae and Pubescentae.
\end{abstract}

\section{Introduction}

Glaucium Mill. (horned poppy), belonging to the family Papaveraceae, is represented by a total of 25 species worldwide, and especially distributed throughout Western, Northern and Eastern Asia, Europe, Northern Africa, and Australia. The distribution of Glaucium species relatively widely covers western Asia and the Mediterranean region and is decreased from central Asia to the European countries. As a country, Iran harbors relatively more species of the genus Glaucium (17 species) and hence, this country is considered as the hot spot of the genus.

The genus Glaucium consists of annual, biennial, and perennial herbaceous plants and grows mostly in saline soils and by the sea. Glaucium is represented by a total of 10 taxa in Turkey, namely G. corniculatum (L) Rud. subsp. corniculatum; G. corniculatum (L) Rud. subsp. refractum (Nab.) Cullen; G. grandiflorum Boiss \& Huet var. grandiflorum; G. grandiflorum Boiss. \& Huet var. torquatum Cullen; G. grandiflorum var. haussknechtii (Bornm. \& Fedde) Parsa; G. flavum Crantz; G. leiocarpum Boiss.; G. acutidentatum Hausskn. \& Bornm.; G. cappadocicum Boiss. and $G$. secmenii Y1ldırıml, four ( $G$. grandiflorum var. torquatum, $G$. acutidentatum, $G$. cappadocicum, G. secmenii) of which are endemic (Seçmen et al. 1998; Yıldırıml, 2012). Turkey ranks second with respect to having the maximum number of species following Iran. A lot of chemical studies have been carried out on the genus. Mory (1979) classified 22 species belonging to the genus into two sections, namely Acropetale and Glaucium. The section Acropetale was more primitive than the section Glaucium. A micro-macromorphological study on 18 Glaucium taxa was carried out by Gran and Sharifnia (2008) based on 28 qualitative and 37 quantitative characters. In the study performed by Vorniceanu et al. (2002), the number of chromosomes of $G$. flavum was measured as $2 \mathrm{n}=12$, and the chromosome lengths of the metaphase stage were measured as 1.30 to $1.78 \mu \mathrm{m}$. In this study, the chromosomes were separated into two groups, and five pairs were identified as metacentric and one pair as submetacentric. Ivanovska and Philipov (1996) revealed that the family Papaveraceae had a

*For correspondence: E-mail: fatmamungankilic@artuklu.edu.tr

${ }^{1}$ Department of Biology, Faculty of Science and Arts, Celal Bayar University, Manisa, Turkey.

${ }^{2}$ Department of Biology, Science Faculty, Ankara University, Ankara, Turkey. 
rich content of isoquinoline alkaloids such as aporphine, protopine, protoberberine and proaporphine. In a phytochemical study performed by Vorniceanu et al., 2004, on the species of Papaveraceae, including G. corniculatum and G. flavum, from which many alkaloids were isolated and identified.

The aim of our study was to identify the widespread distributionof Glaucium taxa in Turkey, to generate detailed descriptions identifying its macro-micromorphological and, palynological properties, to reconstruct its phylogeny through molecular studies (Fig. 1).

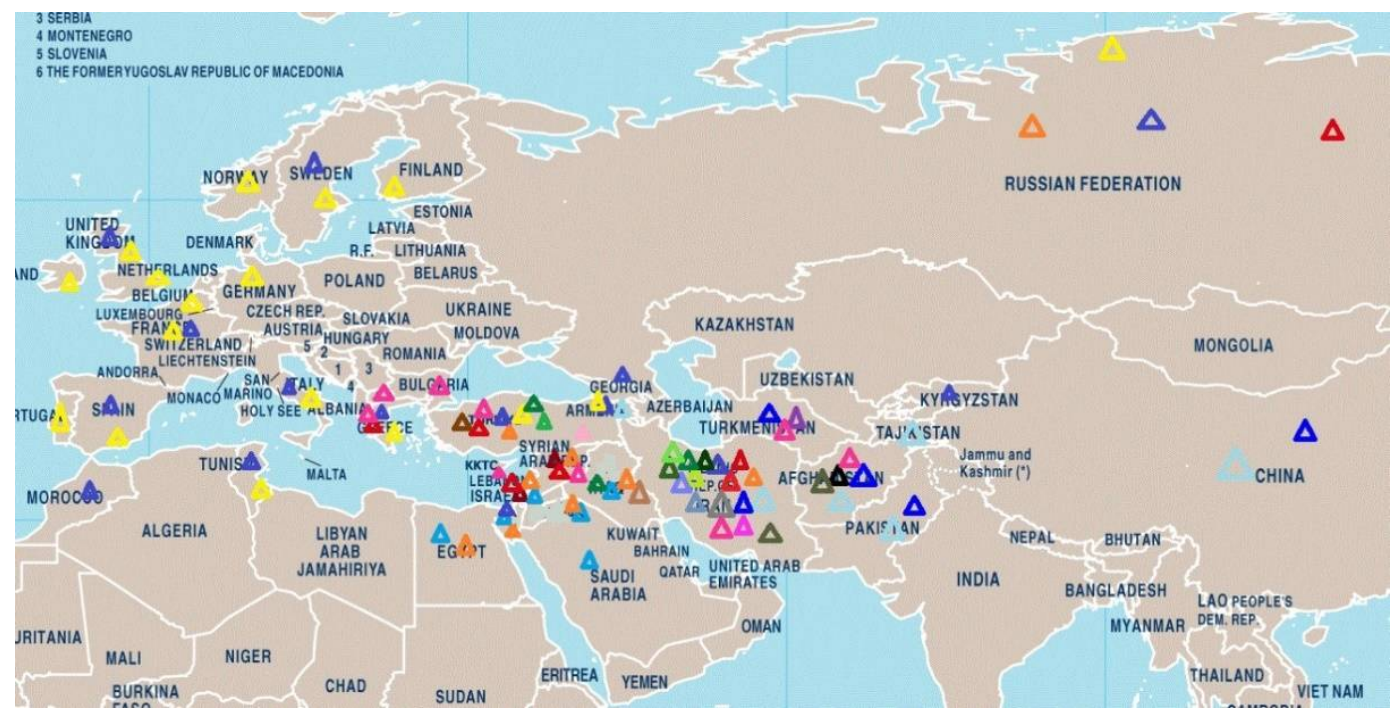

Fig.1. The areas with dense distribution of Glaucium taxa. $(\mathbf{\Delta}=$ Species distributed in Turkey; $\mathbf{\Delta}=$ G. corniculatum, G. grandiflorum, $\mathbf{\Delta}=$ G. secmenii, $\mathbf{\Delta}=$ G. flavum, $\mathbf{\Delta}=$ G. leiocarpum, $\mathbf{\Delta}=$ g. acutidentatum and $\mathbf{\Delta}=G$. cappadocicum)

\section{Materials and Methods}

The specimens of Glaucium taxa were collected from natural populations, necessary field data were recorded and photographs were taken during field vists. Aditionally, the specimens of Glaucium housed in Turkey's major herbaria were studied and significant characters were recorded. The necessarydrawings of taxa were also constructed (Figs 2-3).

For SEM, seed and pollen samples were mounted on stubs using double-sided adhesive tape, coated with gold using a POLARON SC7620 sputter, and then examined and photographed with LEO 440 SEM. Seed analysis was performed according to Stearn (1996) and pollen analysis was performed according to Punt and Hoen (2007).

DNA Isolation: The leaf pieces $(30 \mathrm{mg})$ of ten Glaucium and two Papaver taxa were grinded with the help of microtube pestle in combination with liquid nitrogen in the different $1.5 \mathrm{ml}$ mücrotubes.. Total genomic DNA isolation of the grinded leaf samples were performed with the "Gene MATRIX Plant and Fungi" kit according to the manufacturer's protocol. Isolated DNA concentration of each sample was quantified by Nano Drop ND-1000 spectrophotometer. Stock DNAs were kept at $-20^{\circ} \mathrm{C}$. 

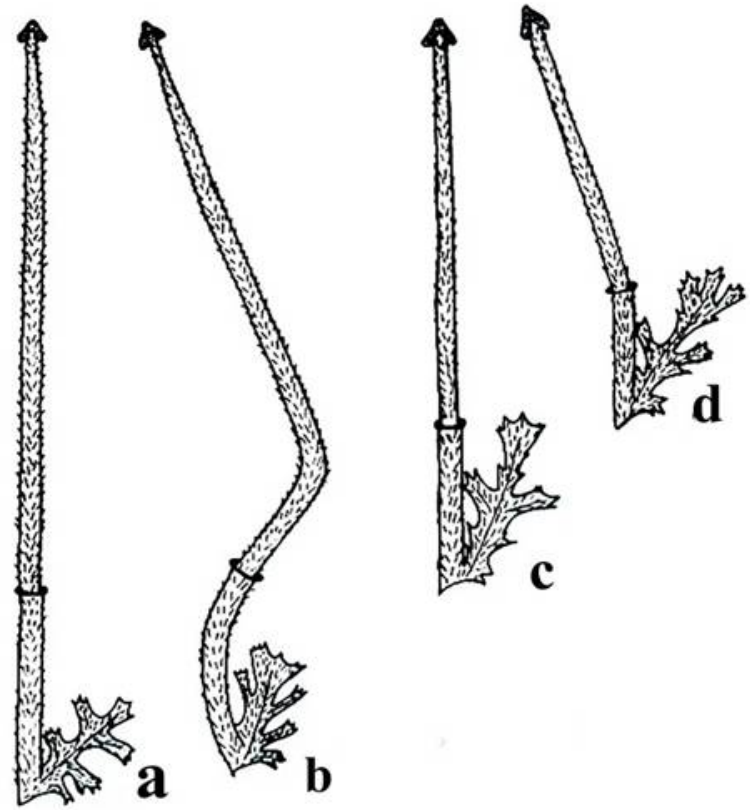

Fig. 2. Fruits of Glaucium taxa of Turkey. a. G. grandiflorum var. grandiflorum; b. G. grandiflorum var. torquatum; c. G. corniculatum subsp. corniculatum; d. G. corniculatum subsp. refractum.
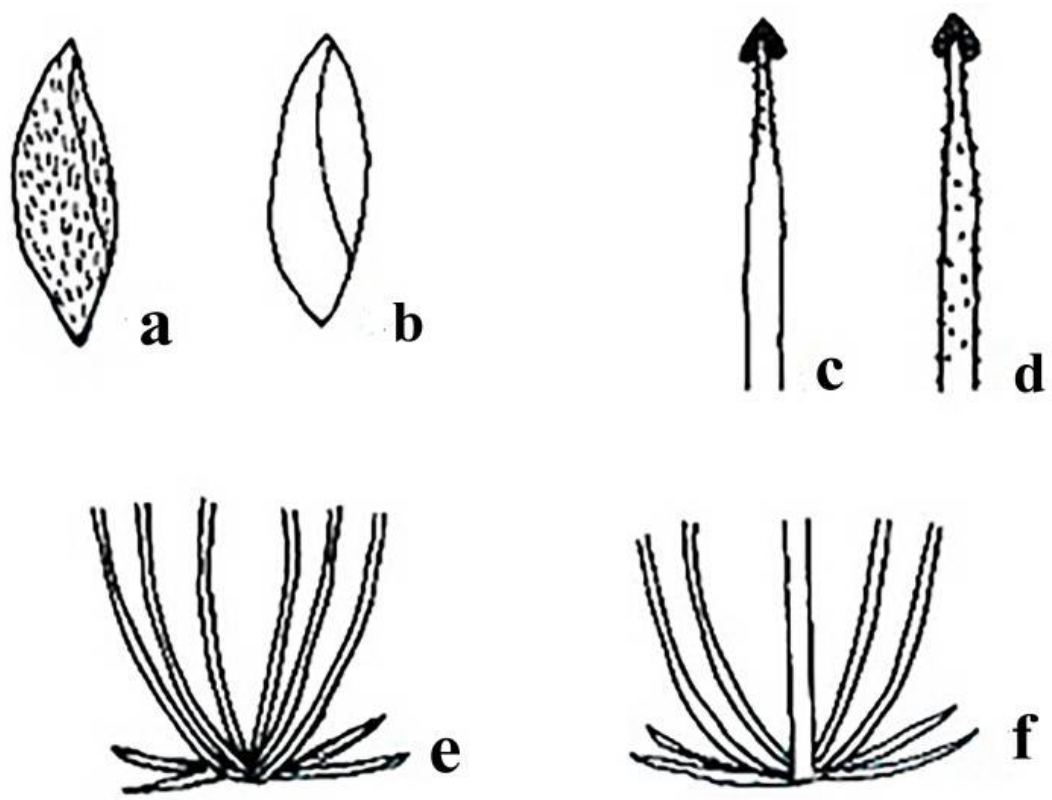

Fig. 3. Plant parts of some Glaucium taxa used for diagnosis: a. Sepal of G. grandiflorum var. grandiflorum;b. Sepal of G.leiocarpum; c. Fruit of G. leiocarum; d. Fruit of G. flavum; e. Stem of G. grandiflorum var. haussknechtii; f. Stem of G. grandiflorum var. grandiflorum. 
PCR amplification and sequencing: matK and ITS3-6 sequences of ten Turkish Glaucium taxa were analyzed. The $m a t K$ region of the chloroplast DNA was amplified with the $m a t K \_390 \mathrm{f}$ and matK_1326r primers and ITS3-6 region of the nuclear DNA was amplified with the ITS-3F and ITS-6R primers (Cuénoud et al., 2002). PCR study was performed with a total $50 \mu$ standard reaction volume for each sample. Optimum amplification conditions were obtained with $100 \mathrm{ng}$ genomic DNA, $1 \times$ reaction buffer, $2.5 \mathrm{mM} \mathrm{MgCl}_{2}, 20 \mu \mathrm{M}$ dNTPs, $0.4 \mu \mathrm{M}$ for matK_390f and matK_1326r primers, 2 U Hot Start Taq DNA polymerase (SolisBioDyne) and a PCR mix was prepared in accordance with the seamounts. Amplification was performed in a Techne Progene Thermal Cycler (Barloworld Scientific, Staffordshire, U. K.). The reaction mixtures were heated in an initial step of $94{ }^{\circ} \mathrm{C}$ for $15 \mathrm{~min}$ and then subjected to 35 cycles of the following program: 95 ${ }^{\circ} \mathrm{C}$ for $45 \mathrm{~s}, 57{ }^{\circ} \mathrm{C}$ for $45 \mathrm{~s}$, and $72{ }^{\circ} \mathrm{C}$ for $1 \mathrm{~min}$. After the last cycle, the temperature was maintained at $72^{\circ} \mathrm{C}$ for $10 \mathrm{~min}$. The amplification products were analyzed by electrophoresis on $1.5 \%$ agarose gel containing ethidium bromide and the product sizes were determined on gels by nucleotide size marker (100 bp ladder; Solis BioDyne). The PCR products were sequenced with a Big Dyecycle sequencing kit (Applied Biosystems, Foster City, California) using an ABI 3130 XL genetic analyzer (Applied Biosystems).

Sequence analysis: The amplified fragments were in duplicate conditions. Alignment of the mat $K$ sequences was generated using the MUSCLE algorithm of MEGA 6 software with default settings (Edgar, 2004; Tamura et al., 2011). Ends of the alignment were trimmed to make all the sequences in the final data set equal in length. The evolutionary history and molecular phylogenetic analysis were inferred using the maximum likelihood (ML) method based on the Tamura-Nei model via MEGA6 software (Tamura et al., 2011). The percentage of replicate trees in which the associated taxa were clustered together in the bootstrap test (1000 replicates) is shown next to the branches. The evolutionary distances (pair-wise distances) were computed, using the maximum composite likelihood model, in units of the number of base substitutions per site (Tamura et al., 2004). The analysis involved 20 nucleotide sequences.

\section{Results and Discussion}

A total of 10 Glaucium taxa were analyzed in terms of their morphological, palynological, and phylogenetic characters. Although some of the morphological characters of the taxa examined were following the information contained in Flora of Turkey (Cullen, 1965), it was noticed that some of their properties were different. In addition, the data yielded from Mory's (1979) study and those yielded as a result of our measurements were compared. In this comparison, the major similarity was observed in terms of the morphological and palynological characters. In a micromacromorphological study performed by Gran and Sharifnia (2008) of 18 Glaucium taxa, the species G. haussknechtii has been recognized as synonymous with G. grandiflorum based on the analyses of 28 qualitative and 37 quantitative characters. As a result of our detailed analyses of morphological, seed, pollen and phylogenetic data, it was revealed that these two species were different.

In this study the Glaucium taxa were divided into two groups with respect to stem hairs. Taxa with pubescence stems were G. corniculatum subsp. corniculatum and G. corniculatum subsp. refractum, G. grandiflorum var. grandiflorum, G. grandiflorum var. torquatum, G. grandiflorum var. haussknechtii and G. secmenii, while the taxa with hairless stems were G. flavum, G. leiocarpum, G. acutidentatum and G. cappadocicum.

The petals of the taxa included in the hairy group were red, or reddish-orange, whilethose with hairless group were yellow or yellowish-orangethe seeds were separated by thin prominent sections. The testa outline of the seeds of taxa with hairy stemswere clearly arch shaped, and 
curved (undulate) (Figs 4-5); while that of the taxa with hairless stemswere smooth or less curved (Figs 4-5).

SEM analysis showedthat the taxa included in the hairy group were variable in pollen shape. Pollens of G. corniculatum subsp. corniculatum and G. grandiflorum var. grandiflorum were suboblate, and that of G. grandiflorum var. torquatum was prolate. The taxa of G. corniculatum subsp. refractum, G. grandiflorum var. haussknechtii and G. secmenii included in the hairy group had spheroidal pollens (Fig. 5, Table 1).

arch shape of testa outline (undulate)

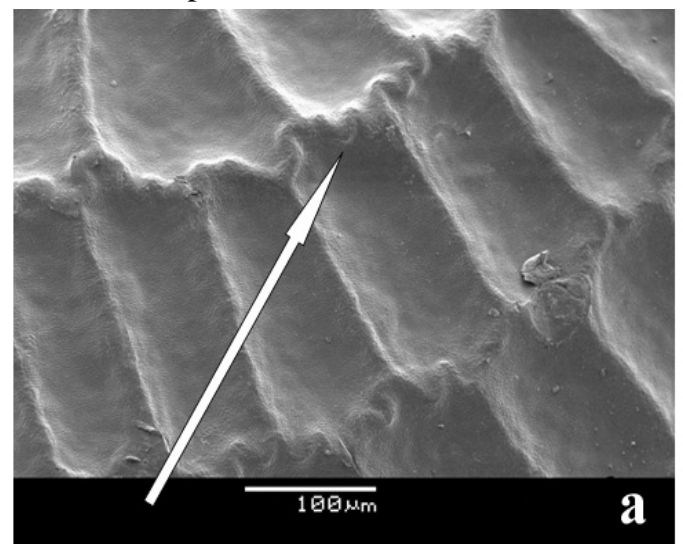

smooth shape

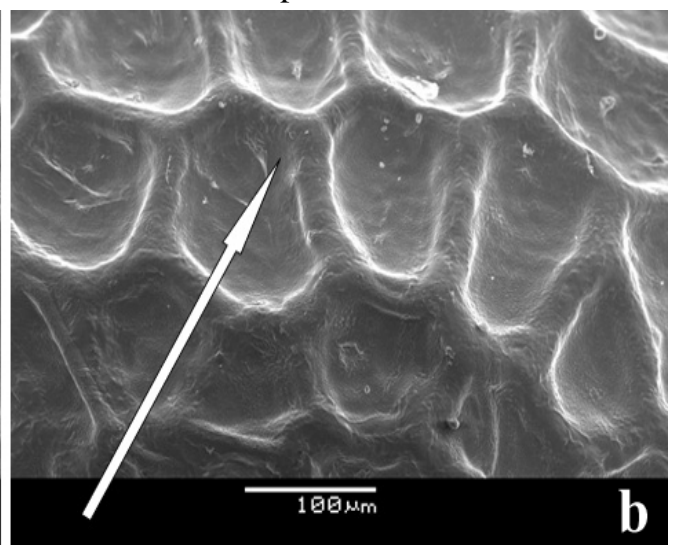

Fig. 4. Testa outline of the seeds of taxa with hairy, i.e. Pubescentae (a) and hairless i.e. Glabrousae (b) stem.

It was observed that in the ML tree based on matK DNA sequences (Fig. 6), the Glaucium taxa were resolved into the moderately to strongly supported G. flavum-G. leiocarpum-G. acutidentatum-G. cappadocicum clade with glabrous stem and the weakly supported or unsupported clade of rest of the taxa studied ( $G$. corniculatum subsp. corniculatum, $G$. corniculatum subsp. refractum, G. grandiflorum var. grandiflorum, G. grandiflorum var. torquatum, G. grandiflorum var. haussknechtii, G. and G. secmenii) with pubescent stem. In the ML tree based on ITS3-6 DNA sequences (Fig. 7), the G. flavum-G. leiocarpum-G. acutidentatum-G.cappadocicum clade was strongly resolved, but clade of rest of the taxa studied was unsupported though G. secmenii and G. corniculatum subsp. refractum were resolved in to a moderately supported clade.

The results of phylogenetic analyses showed that the Glaucium taxa were grouped into two main clades in the ML trees based on the matK and ITS3-6 DNA sequences (Figs 6-7), which is in compatible with the hairness of their stems, petal color and testa outline of the seeds. The taxa included in these two sub-clades were also compatible with ovary tubercle. However, we weren't able to observe the formation of these two sub-clades when we analyzed the ITS3-6 DNA sequences snd the sub-clades of Glaucium taxa based on these morphological characters were not clearly supported by pollen characters, like pollen lenght $(\mathrm{P})$, equatorial width $(\mathrm{E}), \mathrm{P} / \mathrm{E}$ ratio and pollen shape etc., that were mostly overlapping. For example, in G. grandiflorum var. grandiflorum pollens were suboblate, and P/E was 1.51, G. grandiflorum var. torquatumpollens were prolate and P/E was 0.78 , and in G. corniculatum subsp. Corniculatum pollens were suboblate, and P/E was 0.83. In all other Glaucium taxa, pollens were spheroidal, and P/E values falled within the $\mathrm{P} / \mathrm{E}$ range of above-mentioned taxa. 


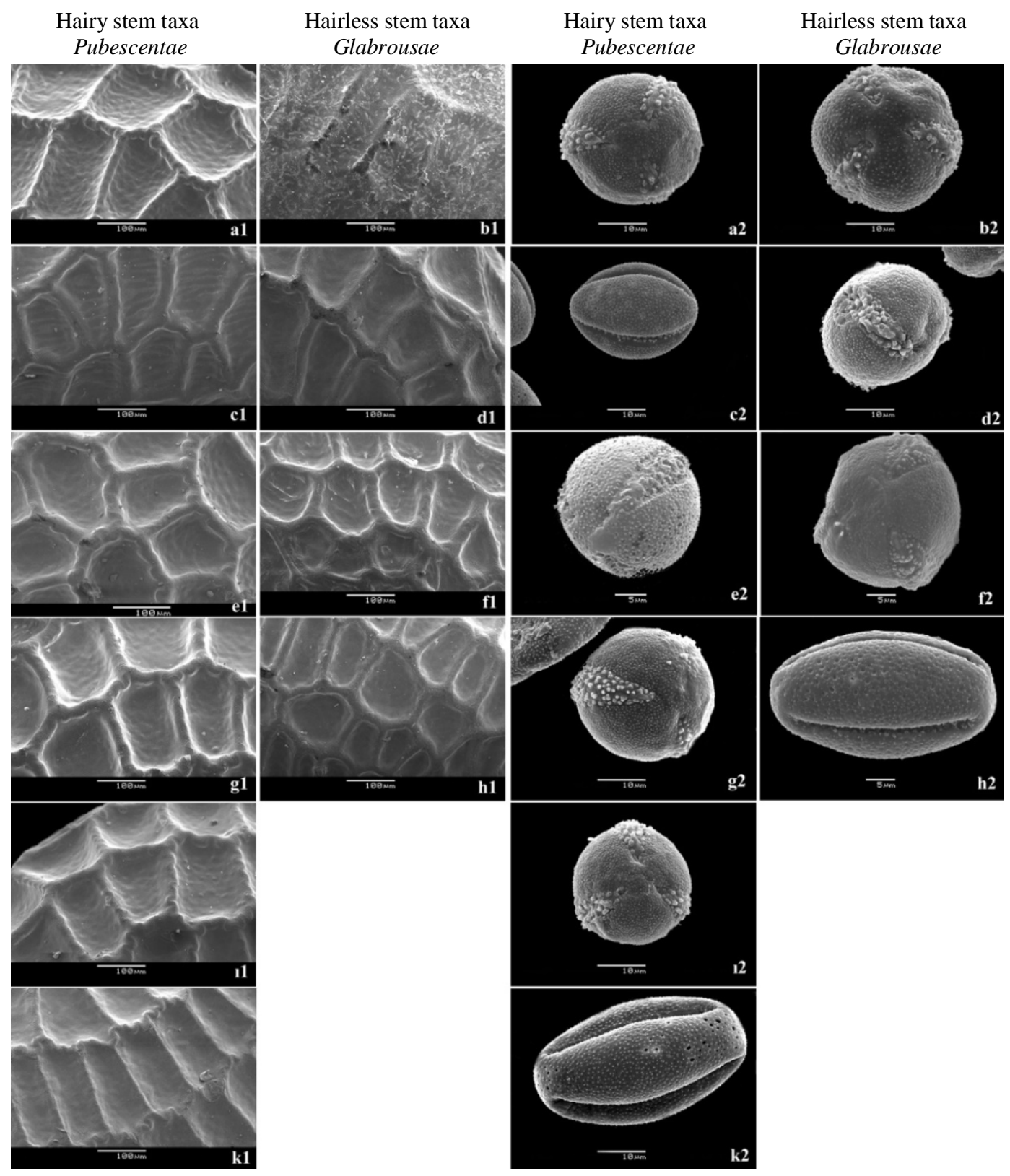

Fig. 5. Glaucium seeds (a1, b1, c1, d1, e1, f1, g1,h1, 11, k1) and pollen (a2, b2, c2, d2, e2, f2, g2,h2, 12, k2) SEM views, a1, a2: G. corniculatum subsp. corniculatum b1, b2: G. flavum c1, c2: G. corniculatum subsp. refractum d1, d2: $G$. leiocarpum e1, e2: G. secmenii f1, f2: G. acutidentatum g1, g2: G. grandiflorum var. grandiflorum h1, h2: G. cappadocicum 11, 12: G. grandiflorum var. torquatum k1, k2: G. grandiflorum var. haussknechtii.

It was foundthat $G$. grandiflorum var. grandiflorum and $G$. grandiflorum var. torquatum constituted a small sub-clade and the difference between them was minimal. They were also morphologically separated from each other in terms of the position of the fruit's pedicel, and the pollen's shape. The fruit's pedicel of G. grandiflorum var. grandiflorum was vertical, and the 
pollen's shape was suboblate while the fruit' pedicel of G. grandiflorum var. torquatum was curved, and the pollen' shape is prolate.

G. corniculatum subsp. refractum and G. secmenii constituted a sub-clade in the ML tree based on ITS3-6 DNA sequences, but not in that based on matK DNA sequences.Both taxa's fruit pedicels were curved and their pollens were spheroidal. To know the relationship between these two taxa needs further study.

Table 1. The comparative pollen properties of Glaucium taxa.

\begin{tabular}{|c|c|c|c|c|c|}
\hline $\begin{array}{l}\text { Pollen properties } \\
\text { Taxa }\end{array}$ & $\begin{array}{l}\text { Pollen lenght } \\
\text { (P) } \\
\text { Min-max } \\
\text { Mean } \\
(\mathrm{SD}) \mu \mathrm{m}\end{array}$ & $\begin{array}{l}\text { Equatorial } \\
\text { width (E) } \\
\text { Min-max } \\
\text { Mean } \\
\text { (SD) } \mu \mathrm{m}\end{array}$ & $\begin{array}{l}\mathrm{P} / \mathrm{E} \\
\text { ratio }\end{array}$ & Pollen shape & \\
\hline $\begin{array}{l}\text { G. corniculatum subsp. } \\
\text { corniculatum }(465-2)\end{array}$ & $\begin{array}{l}24-35 \\
32,96(2.12)\end{array}$ & $\begin{array}{l}37-41 \\
39,53(1.19)\end{array}$ & 0.83 & Suboblate & \\
\hline $\begin{array}{l}\text { G. corniculatum subsp. } \\
\text { refractum }(467)\end{array}$ & $\begin{array}{l}28-33 \\
30,73(1.28)\end{array}$ & $\begin{array}{l}32-35 \\
33,73(1.01)\end{array}$ & 0.91 & Spheroidal & \\
\hline G. secmenii (587) & $\begin{array}{l}19-30 \\
24,5(2,59)\end{array}$ & $\begin{array}{l}20-34 \\
25,5(2,75)\end{array}$ & 0.91 & Spheroidal & Pubescentae \\
\hline $\begin{array}{l}\text { G. grandiflorum var. } \\
\text { grandiflorum (416) }\end{array}$ & $\begin{array}{l}27-37 \\
29,1(2.00)\end{array}$ & $\begin{array}{l}34-46 \\
37,06(2.21)\end{array}$ & 0.78 & Suboblate & \\
\hline $\begin{array}{l}\text { G. grandiflorum var. } \\
\text { torquatum (354-1) }\end{array}$ & $\begin{array}{l}29-34 \\
29,5 \\
(1.49)\end{array}$ & $\begin{array}{l}18-23 \\
18,5(1.13)\end{array}$ & 1,51 & Prolate & \\
\hline $\begin{array}{l}\text { G. grandiflorum var. } \\
\text { haussknechtii (456) }\end{array}$ & $\begin{array}{l}28-35 \\
30,26(1.55)\end{array}$ & $\begin{array}{l}32-40 \\
34,26(1.76)\end{array}$ & 0.88 & Spheroidal & \\
\hline G. flavum (460) & $\begin{array}{l}31-37 \\
33,4(1.67)\end{array}$ & $\begin{array}{l}33-40 \\
37,46(1.67)\end{array}$ & 0.89 & Spheroidal & Glabrousae \\
\hline G. leiocarpum (415) & $\begin{array}{l}30-37 \\
33(1.41)\end{array}$ & $\begin{array}{l}28-38 \\
34.5(3,53)\end{array}$ & 0.94 & Spheroidal & \\
\hline G. acutidentatum (440) & $\begin{array}{l}25-31 \\
29.5(1.87)\end{array}$ & $\begin{array}{l}28-40 \\
31.9(2.10)\end{array}$ & 0.92 & Spheroidal & \\
\hline G. cappadocicum (449) & $\begin{array}{l}25-36 \\
30,3(1.88)\end{array}$ & $\begin{array}{l}26-37 \\
33,06(2.06)\end{array}$ & 0.91 & Spheroidal & \\
\hline
\end{tabular}

Mory (1979) divided Glaucium taxa into two sections (Acropetale and Glaucium). Glaucium taxa into two sections are supported by our study, and our all Glaucium taxa belong to Mory's section Glaucium. In our research, it was determined Mory's section Glaucium we can be divided into two sub-sections.

Since these subsections clearly differ from each other, it was concluded that the nomenclature should be cited as Subsection Glabrousae K. Y1ldiz \& Mungan and Subsection Pubescentae K.Yıldız \& Mungan. 
According to these results, the identification key of Glaucium species that have grown in flora of Turkey was performed as follows:

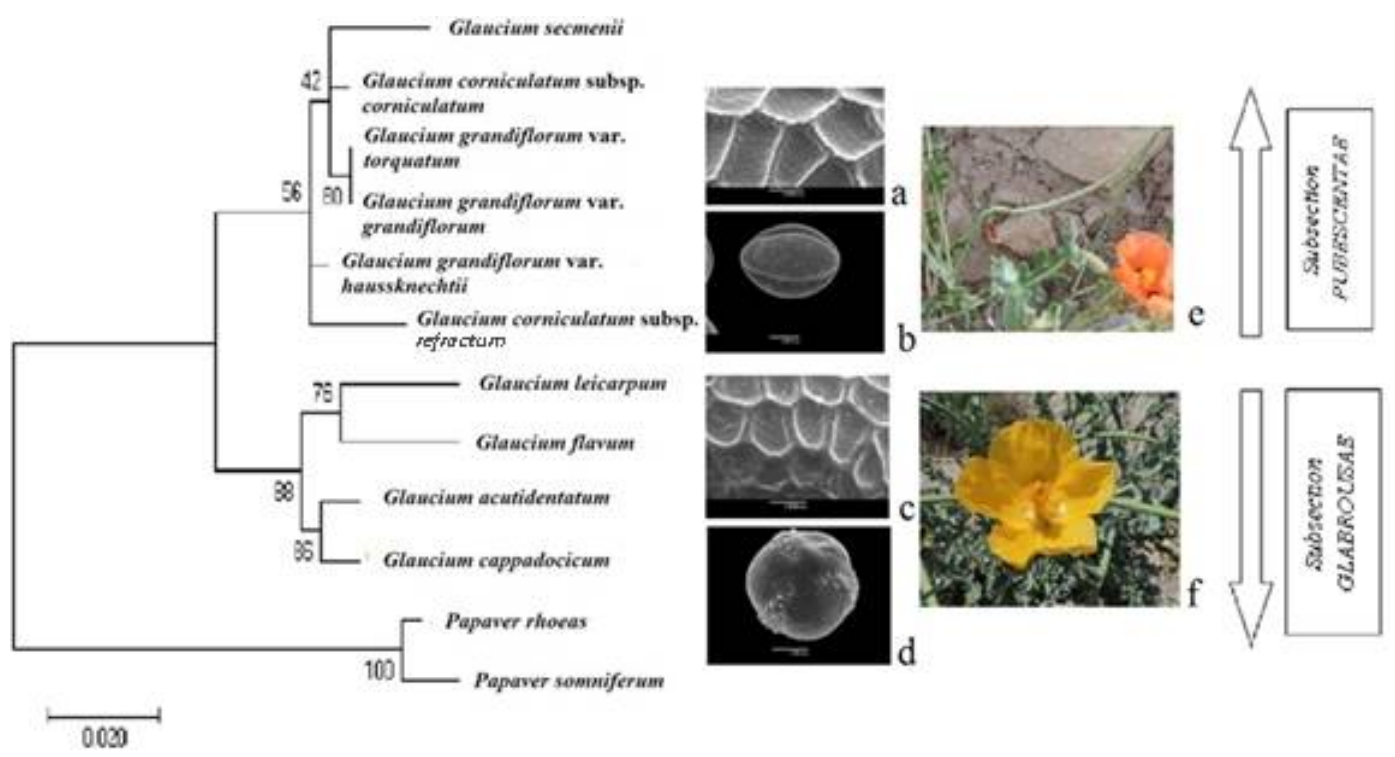

Fig. 6. ML tree based on matK DNA sequence of the Subsections Pubescentae and Glabrousae. Pubescentae; a. Seed surface b. Pollen e. morphological appearance, and Glabrousae; c. Seed surface d. Pollen f. morphological appearance.

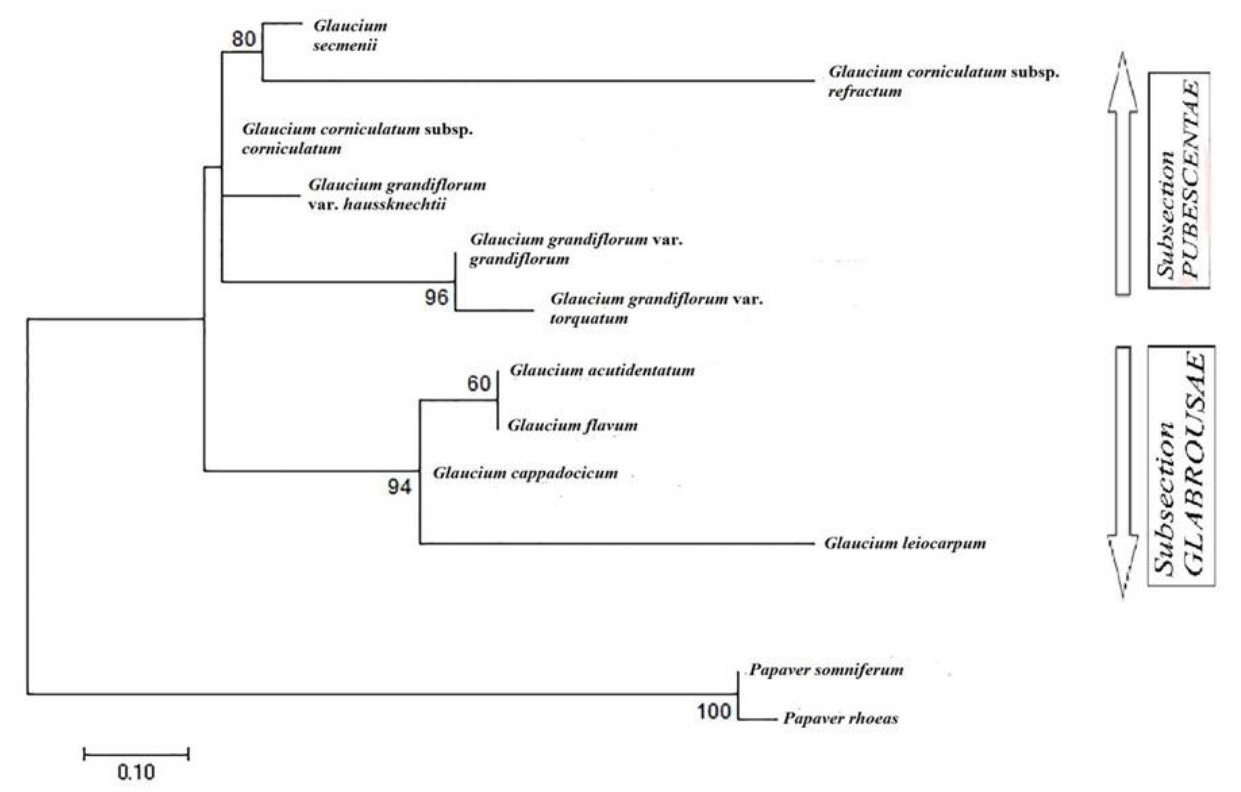

Fig. 7. ML tree based on ITS3-6 DNA sequences of the subsections Pubescentae and Glabrousae. 
1. Stem and ovary pilose with adpressed or subspreading hairs

2. Fruiting pedicels shorter than the leaves subtending them

3. Sepals $1-2.7 \mathrm{~cm}$; petals $1.5-3.5 \times 1.4-2.8 \ldots \ldots \ldots \ldots \ldots \ldots \ldots \ldots . .1$. corniculatum

3. Sepals $0.7-2.5 \mathrm{~cm}$; petals $1.2-2.2 \mathrm{x} 1-2.1 \ldots \ldots \ldots \ldots \ldots \ldots \ldots .2$. secmenii

2. Fruiting pedicels exceeding the leaves subtending them......

3. grandiflorum

1. Stem glabrous, Ovary tuberculate or glabrous never pilose

4. Ovary papillose- tuberculate, at least near the apex

5. Upper leaves sinuate-dentate with obtuse or rounded lobes; fruit neither torulose nor attenuate at the apex, petals yellow.... 4. flavum

5. Upper leaves pinnatifid, with acute segments; fruit somewhat torulose, attenuate at the apex, 5. leiocarpum

4. Ovary smooth, etuberculate

6. Radical leaves deeply pinnatifid; sepals greyish-black. 6. acutidentatum

6. Radical leaves obovate-runcinate, dentate; sepals green 7. cappadocicum

\section{References}

Cuénoud, P., Savolainen, V., Chatrou, L.W., Powell, M., Grayer, R.J. and Chase, M.W. 2002. Molecular phylogenetics of Caryophyllales based on nuclear $18 \mathrm{~S}$ rDNA and plastid rbcL, atpB, and matK DNA sequences. American J of Bot. 89: 132-144.

Cullen, J. 1965. GlauciumMill. In Davis PH.Editors.Flora of Turkey and the East Aegean Islands, Vol. 1.1st ed. Edinburgh, UK. Edinburgh University Press. pp. 219-236.

Edgar, R.C. 2004. MUSCLE.A multiple sequence alignment method with reduced time and space complexity. BMC Bioinformatics 5: 113.

Gran, A. and Sharifnia, F. 2008. Micro-macromorphological studuies of the genus Glaucium (Papaveraceae) in Iran. Iran. J. Bot.14: 23-38.

Ivanovska, N. and Philipov, S. 1996. Comparative Study on the Immunological Activity of a Series of Isoquinoline Alkaloids. Phytotherapy Research. 10: 62-65.

Mory, B. 1979. Beiträge zur Kenntnis der Sippenstruktur der Gattung Glaucium Miller (Papaveraceae). Feddes Repertorium.89: 499-544.

Punt, W. and Hoen, P.P. 2007. Blackmore S., Nilsson S., Le Thomas A. Glossary of pollen and spore terminology. Review of Palaeo botany and Palynology. 143: 1-81.

Seçmen, Ö., Gemici, Y., Görk, G., Bekat, L., Leblebici, E. 1998. Tohumlu Bitkiler Sistematiği, Ege Üniv. Basımevi, Bornova-İzmir. pp. 236-240.

Stearn, W.T. 1996. David \& Charles, fourth edit. Botanical Latin. London. 489-491.

Tamura, K., Nei, M. and Kumar, S. 2004. Prospects for inferring very large phylogenies by using the neighbor-joining method. Proceedings of the National Academy of Sciences USA. 101: 11030-11035.

Tamura, K., Peterson, D., Peterson, N. and Stecher, G. 2011. Nei M., Kumar S. MEGA5: Molecular evolutionary genetics analysis using maximum likelihood, evolutionary distance, and maximum parsimony methods. Molecular Biology and Evolution 28:2731-2739.

The Global Biodiversity Information Facility. Website: http:// www.gbif.org/species/2888419 [accessed 10 February 2014].

The Plant List, A Working List of all Plant Species Website: http://www.theplantlist.org/1.1/ browse/ A/Papaveraceae/Glaucium/[accessed 02 April 2013]. 
Vorniceanu, C., Bara, I.I., Moraruu, A. and Costica, N. 2002. The Study of Mitotic Chromosomes at the Glaucium flavum Cr. $(2 \mathrm{n}=12)$ and Chelidonium majus L. $(2 \mathrm{n}=12)$ Species. Analele Stiintifice ale Universitatii" Alexandru Ioan Cuza" din Iasi Sec. II a. Genetica si Biologie Moleculara. 5: 1.

Vorniceanu, C., Vatui, M., Ionescu, A. and Zamfirache, M.M. 2004. Bara I. Contributions to the chemical study of some Papaveraceae species capsulesN.II. Glaucium flavum, Glaucium corniculatum and Chelidonıum majus Annals of the "Alexandru Ioan Cuza" University Sect. II a. Genetics and Molecular Biol. 5.

Yıldırıml, Ş. 2012. Türkiye'nin jipizçin bitki çeşitliliği cenneti: Kepen, Sivrihisar, Eskişehir, 13 yeni üye, Türkiye, OT Sistematik Botanik Dergisi.19: 34-38.

(Manuscript received on 7 July, 2019; revised on 8 December, 2019) 